\title{
An Autonomous Maintenance Design Based on Overall Resource Effectiveness (ORE) Analysis: A Case Study of Paving Molding Machine
}

\begin{abstract}
Indira Kusuma Wardani ${ }^{1 \mathrm{a}}$, Fransiskus Tatas Dwi Atmaji ${ }^{1 \mathrm{~b}}$, Judi Alhilman ${ }^{1 \mathrm{c}}$
Abstract. The paving molding machine is one of the machines used to produce black paving at PT XYZ. Based on the historical data from the engineering maintenance department, this machine has the highest breakdown frequency which affected the low performance and productivity of the machine. To solve this problem, the effectiveness of the paving molding machine was analyzed using overall resource effectiveness (ORE) methods. ORE aims to analyze machine indicators, consisting of readiness, availability of the facility, changeover efficiency, and availability of material, availability of manpower, performance efficiency, and quality rate. The ORE analyzed result shows that values of performance efficiency of paving molding machine were $64.54 \%$ and still below the standards of the ORE. To increase the ORE, a design of autonomous maintenance (AM) was proposed. The proposed design means the operator is given the responsibility to maintain the basic condition of the machine to minimize the damage of the paving molding machine at PT XYZ. The result of ORE analysis, especially in the performance efficiency, will be an input for the engineering maintenance department to make an AM basic design that can be executed by each of the machine's operators. In general, this research's novelty is to combine the application of the ORE method with the AM basic design, whereas the AM is one of the pillars of total productive maintenance (TPM).
\end{abstract}

Keywords: overall resource effectiveness (ORE), autonomous maintenance (AM), breakdown, effectiveness

\section{INTRODUCTION}

The machine is one of the important elements to support the production process in a manufacturing company (Dewi et al., 2020). When the machine works continuously to produce products for twenty-four hours, a machine maintenance system is needed to ensure the machine is in good condition and can run the production process (Alhilman \& Atmaji, 2017). Machine maintenance is generally defined as a combination of all technical, administrative, and managerial actions during a given cycle to maintain the condition of the machine can function optimally to meet the needs (Bokrantz et al., 2020). The purpose of machine maintenance is to maintain machine safety so that it can operate

\footnotetext{
1 Industrial and System Engineering School, Telkom University, Jl. Telekomunikasi No.1, Terusan Buah Batu, Bandung, 40257, Indonesia

a email: indirasena493@gmail.com

b email: franstatas@telkomuniversity.ac.id

c email: alhilman@telkomuniversity.ac.id

- corresponding author
}

Submited: $30-08-2021$

Accepted: 20-12-2021 properly and need a good, precise, and consistent strategy to maintain the production process (Salsabila et al., 2020). Machine maintenance systems are generally divided into two, namely preventive maintenance and corrective maintenance. Corrective maintenance is a maintenance activity that is carried out after a component or system is damaged. While preventive maintenance is a maintenance activity carried out to prevent damage to components or systems (Fay, 1967).

Based on (Alhilman \& Abdillah, 2019) machine maintenance is closely related to the problem of machine efficiency and effectiveness. Therefore, action is needed to prevent or solve machine downtime problems (Dewi et al., 2020). If a company has low machine effectiveness, it will affect the production process so that it cannot fulfill production targets and customer demand. To determine the effectiveness of a machine, one of the methods in machine maintenance management, is overall equipment effectiveness (OEE). OEE is a quantitative metric used to control and improve the productivity of production equipment and improve machine performance in the manufacturing industry (Tsarouhas, 2013). According to research by (Nakajima, 1988), OEE is 
based on three indicator aspects, which are availability $(A)$, performance efficiency $(P)$, and quality rate $(\mathrm{Q})$. The purpose of $\mathrm{OEE}$ is as a measuring tool for a maintenance system to determine machine availability, production efficiency, and quality rate produced by the machines. Based on research (Eswaramurthi \& Mohanram, 2013), the development of the OEE method in the company's production line becomes overall resource effectiveness (ORE) to see the effectiveness of all factors in the company. ORE can also be analyzed on a machine by considering factors that are not known to be resource factors in OEE. So that the ORE method can find out other factors that affect the effectiveness of the machine.

Based on (Aprina, 2019) effectiveness measurement using ORE is good enough to increase the effectiveness of resources. The results show that the proposed method of ORE will help organizations to initiate improvement activities towards improving the overall performance of resources by identifying problems thereby achieving business excellence with effective utilization of available resources.

Based on (Workineh \& Iyengar, 2014) Total Productive Maintenance (TPM) is used to improve production and reduce of cost of production. TPM is a concept aimed at significantly increasing the production in a manufacturing plant and ensuring high employee job satisfaction and customer satisfaction. TPM has eight pillars, namely autonomous maintenance, focused maintenance, planned maintenance, quality maintenance, education and training, office TPM, development management, and safety (Priyono et al., 2019). The implementation of TPM will increase the company's productivity and will also not neglect machine maintenance properly and correctly (monitoring and maintaining all machines in a planned manner) (Budihardjo \& Marisa, 2009).

Autonomous maintenance is one of the pillar TPM that can eliminate the minor equipment shutdowns and faster recovery from a machine breakdown (Workineh \& Iyengar, 2014). Autonomous maintenance is the independent maintenance undertaken by the operators of machines and for the technicians dedicated to the maintenance (Ferreira \& Leite, 2016).

PT $X Y Z$ is one of the fastest-growing construction service companies in Bali. This company has built infrastructure and maintenance projects in Bali, both government and non-government, such as public facilities including airports, roads, bridges, environmental maintenance projects, etc. One of the products produced is black paving $10 \times 2 \times 8 \mathrm{~cm}$. In the production of this paving, four machines are used, there is hopper, mixer, pallet input, and molding machine. These four machines work continuously and only one unit so that the machine is often damaged. From the observations, it is found that the most frequently damaged machine in the production process is the paving molding machine. The following is a graph of machine damage from June 2018 December 2019 (see Figure 1).

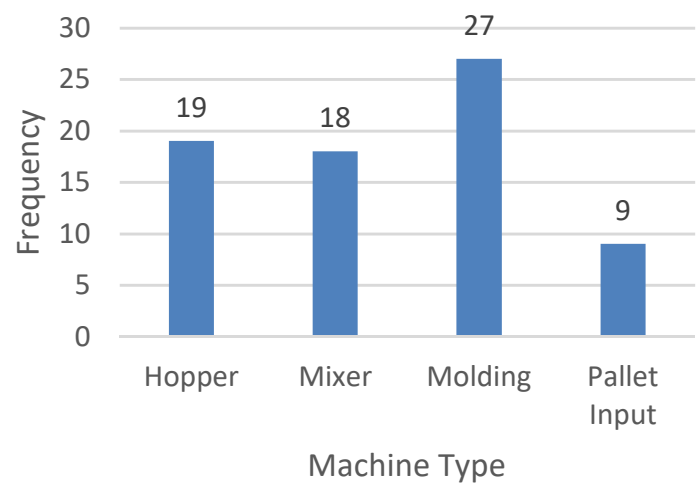

Figure 1. The frequency of damage in paving production June 2018 - December 2019.

Figure 1 shows the frequency of damage in paving the production line, where the paving molding machine has the highest damage frequency among other machines.

This high frequency of damage causes this paving molding machine to have high downtime. Maintenance activities carried out by PT XYZ are corrective maintenance, that maintenance carried out after the machine is damaged. This can affect the effectiveness of the paving molding machine 
in terms of availability, performance, and quality of the machine produced.

To increase the effectiveness of machines, this paper proposes an autonomous maintenance system based on an analysis of machine effectiveness using the overall resources (material, human, method) of a company. The differences between this research with the previous research are the application of the overall resource effectiveness method that combines with the proposed autonomous maintenance by the machine's operator.

\section{RESEARCH METHOD}

This research is used the ORE method for analyzing the data and proposed an autonomous maintenance design based on the result of ORE analysis. The data which used in this analysis is from the 2018-December 2019 period. The data which used in this study is the total operating machine, machine downtime, and production data. Machine downtime consists of planned machine downtime, breakdown machine, setup and adjustment, manpower absence time, and material shortages. The flow of work in this paper can be seen in Figure 2. The first step is determining the object of the research, which is the paving molding machine based on the highest frequency of damage. The ORE calculation is performed by multiplying the seven indicators, there are readiness, availability of the facility, changeover efficiency, availability of material, availability of manpower, performance efficiency, and quality rate (Eswaramurthi \& Mohanram, 2013).

Subsequently, from the results of the ORE calculation, an analysis of the ORE value and the causes of the low ORE value is carried out. After analyzing the OEE calculation, a proposal is made using one of the pillars of TPM, namely autonomous maintenance. Autonomous maintenance is the activities performed by the operator with the sensibility of a little change that takes place in the machine under his responsibility (Ferreira \& Leite, 2016). There are seven steps in the implementation of autonomous maintenance, namely initial cleaning, countermeasure at the source of problems, cleaning and lubrication standards, general inspection, autonomous inspection, organization and tidiness, full autonomous maintenance (Ferreira \& Leite, 2016). The initial cleaning is the step operators clean and inspects their machines and equipment. After the initial cleaning activity, eliminate dirt sources and inaccessible places. The next step is to search for an optimal operating state in the workplace with the cleaning and lubrication standards. Then, do an autonomous inspection to zero defects of the machine. After that, organization and tidiness are about the organization surrounding the machines and equipment well as the correct use of resources. The last step is full autonomous maintenance, the operator is proficient and able to perform maintenance on the machine used.

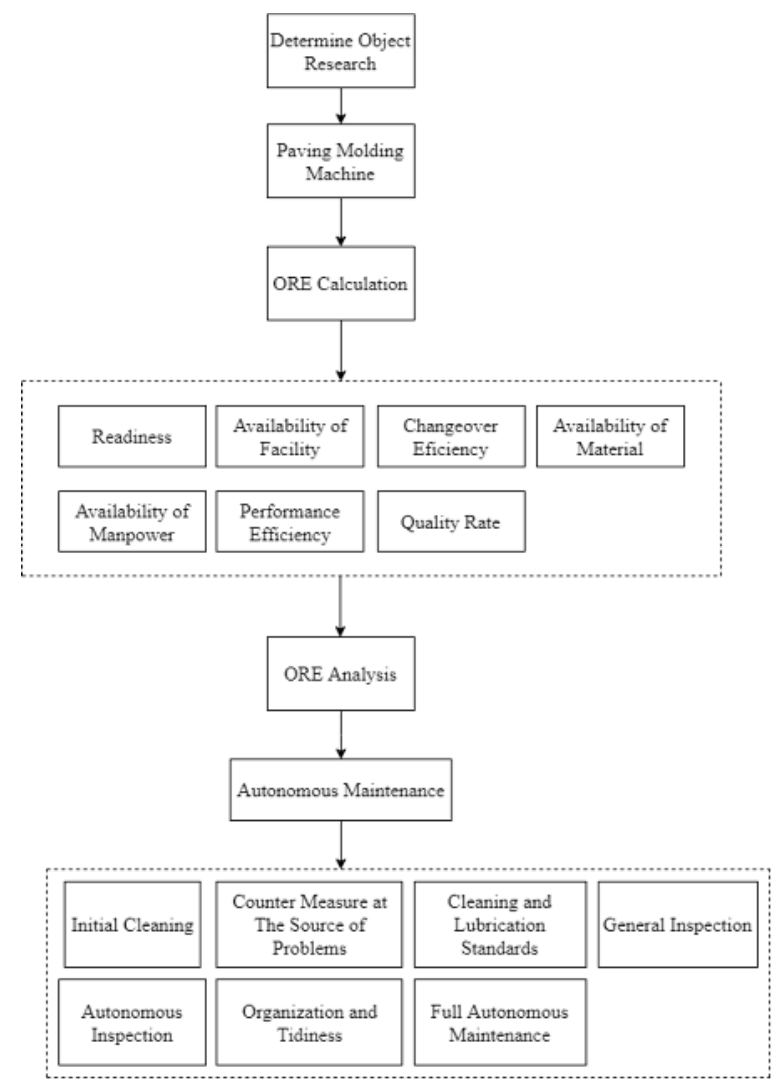

Figure 2. Conceptual Model

The ORE can be used to assist decisionmaking for further analysis and improve resource performance. ORE can be used as a calculation to calculate the effectiveness of resources in the company. (Eswaramurthi \& Mohanram, 2013). 
Readiness. Readiness is the total time when the machine/equipment is not ready to operate due to preparation or planned activities.

$$
R=\frac{\text { Planned Production Time }}{\text { Total Time }}
$$

Availability of Facility. Availability of facility is the total time when the machine is not operating due to a stop in the equipment, such as damage to the machine and accessories, unavailability of tools, and other damage to equipment facilities.

$$
A_{f}=\frac{\text { Loading Time }}{\text { Planned Production Time }}
$$

Changeover Efficiency. Changeover efficiency is the total time when the machine is not operating due to setup and adjustment.

$$
C=\frac{\text { operation Time }}{\text { Loading Time }}
$$

Availability of Material. Availability of material is the total time when the machine is not operating due to the absence of material.

$$
A_{m}=\frac{\text { Running Time }}{\text { operation Time }}
$$

Availability of Manpower. Availability of manpower is the total time when the system does not operate due to the absence of labor so that the production process stops.

$$
A_{m p}=\frac{\text { Actual Running Time }}{\text { Running Time }}
$$

Performance Efficiency. Performance efficiency is the ratio of the actual production level to the expected production level.

$$
P=\frac{\text { Quantity Produced } \times \text { Ideal Cycle Time }}{\text { Actual Running Time }}
$$

Quality Rate. Quality rate is the ratio between the amount of production that is good with the total amount of product processed.

$$
Q=\frac{\text { Quantity Produce-Quantity Product Defect }}{\text { Quantity Produce }}
$$

\section{RESUlT AND DisCUSSION}

\section{ORE Calculation}

ORE calculation is completed by multiplying seven factors, specifically readiness, availability of the facility, changeover efficiency, availability of material, availability of manpower, performance efficiency, and quality rate. The result of the ORE calculation can be seen in Figures 3 to 9 .

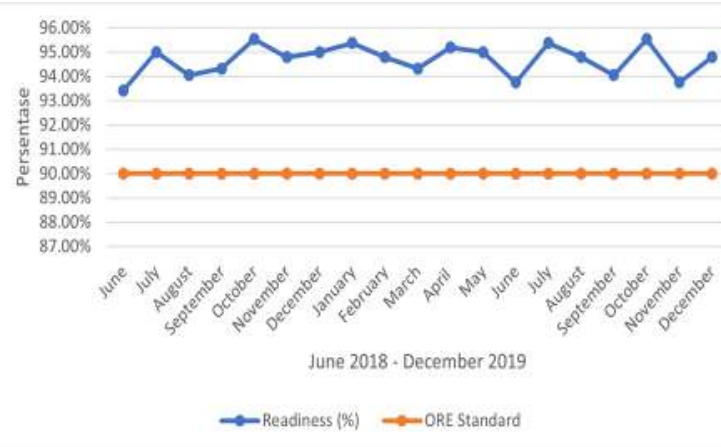

Figure 3. Readiness

Figure 3 shows the graph of machine readiness value. Based on Figure 3 the readiness value analysis has met the standard. The average value of readiness is $94.67 \%$. The fulfillment of this readiness value standard indicates that the planned production time is available for the paving molding machine operating time.

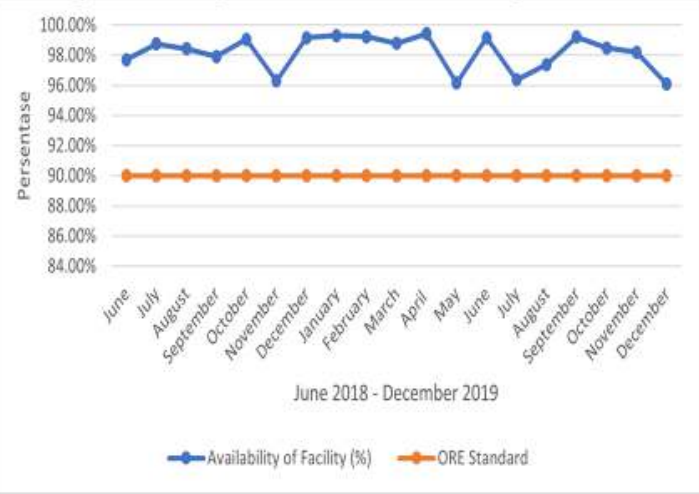

Figure 4. Availability of facility

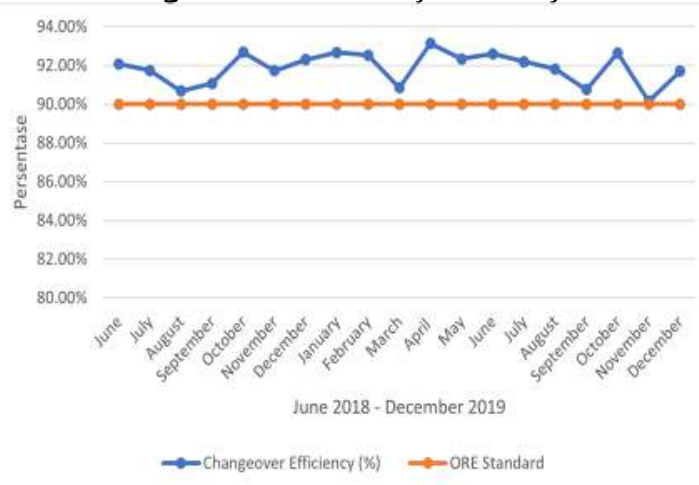

Figure 5. Changeover efficiency

Figure 4 shows the availability of facility value for also has met the standard. The average value of the availability of the facility is $98.16 \%$. The fulfillment of the availability of facility value standard indicates that the paving molding machine does not have a long breakdown time so 
that the production process can still take place even though there are delays and must pursue production targets.

Meanwhile, Figure 5 shows that the changeover efficiency value meets up the standard whereas the average value of changeover efficiency is $91.88 \%$. The standard fulfillment of the changeover efficiency value is influenced by the setup and adjustment time of the paving molding machine. Its means that the process of setup and adjustment is relatively effective during the production process.

Figure 6 shows that, the availability of material analysis has met the standard. This shows that in the production of material delays or raw materials for the production process is very low so that it does not interfere with the production process too much.

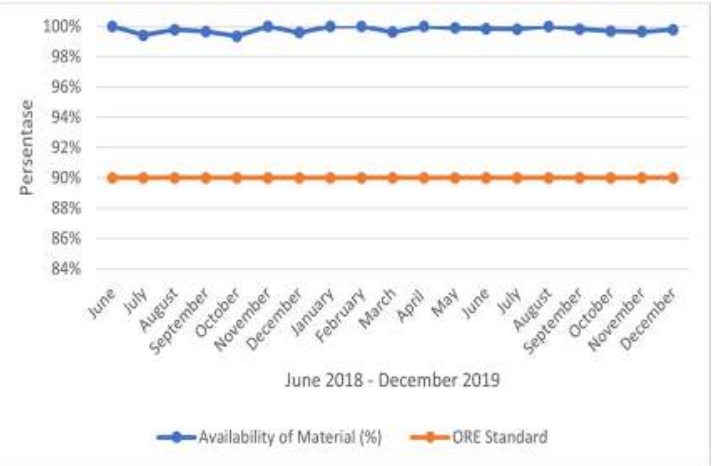

Figure 6. Availability of Material

Moreover, based on Figure 7 the availability of manpower also has met the standard which the average value is $97.52 \%$. The fulfillment of the availability of manpower value standard is influenced by the operator's presence during the production process. It means the operator is ready and available during the production process.

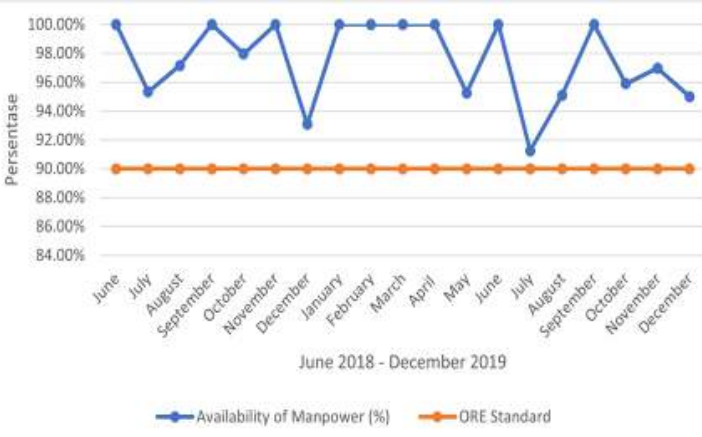

Figure 7. Availability of Manpower

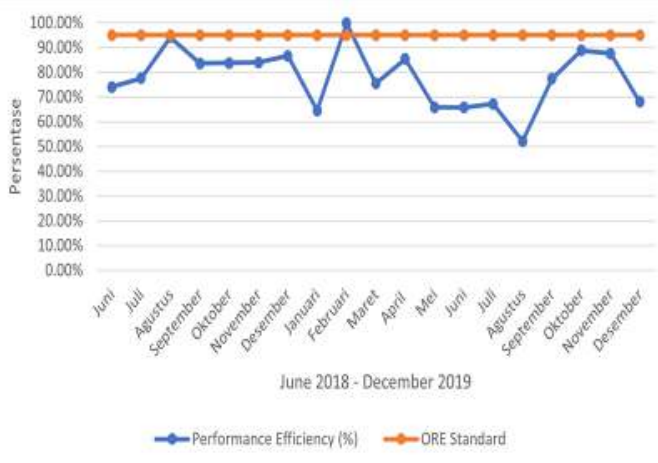

Figure 8. Performance Efficiency

Based on Figure 8 the performance efficiency value of the paving molding, only in November 2019 met the standard, which was $99.80 \%$. The others value of performance efficiency is in the range of $52.16 \%$ to $99.80 \%$ with an average performance efficiency of $77.98 \%$.

The low value of performance efficiency is caused by the difference between the actual production time and the expected production time, which affects the amount of paving production.

Figure 9 shows the quality rate result of the paving molding machine which is $99.43 \%$. The standard fulfillment of the quality rate value is influenced by the low number of defects so that the amount of production can meet the company's standard. To simplify the result from previous figures, the average ORE calculation is shown in Table 1. 


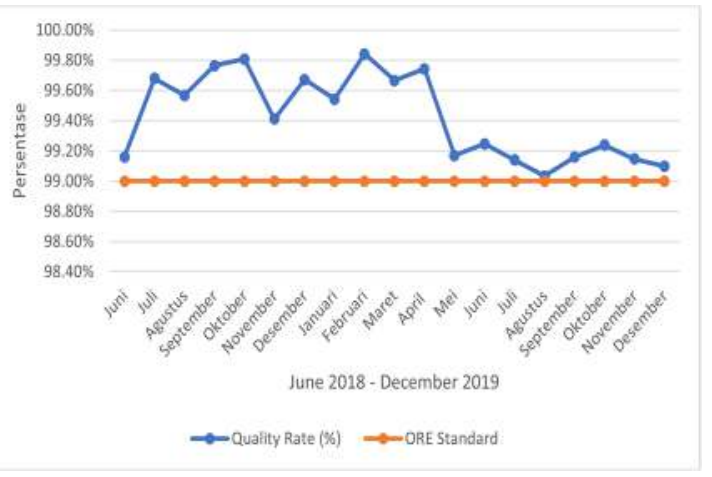

Figure 9. Quality Rate

Table 1. Average of ORE

\begin{tabular}{lcc}
\hline \multicolumn{1}{c}{ ORE Factors } & Result & ORE Standards \\
\hline Readiness & $94.67 \%$ & $90 \%$ \\
Availability of Facility & $98.16 \%$ & $90 \%$ \\
Changeover Efficiency & $91.88 \%$ & $90 \%$ \\
Availability of Material & $99.79 \%$ & $90 \%$ \\
Availability of Manpower & $97.52 \%$ & $90 \%$ \\
Performance Efficiency & $77.98 \%$ & $95 \%$ \\
Quality Rate & $99.43 \%$ & $99 \%$ \\
ORE & $64.54 \%$ & $85 \%$ \\
\hline
\end{tabular}

Table 1 shows the average ORE value compared to global ORE standards. The ORE result is $64.54 \%$ which is below the standard of ORE. Form the eight factors, the value performance efficiency does not meet global ORE standards, the value is $77.98 \%$. Therefore, it affects the total effectiveness of the machine and ORE does not reach $85 \%$. To solve this lowperformance efficiency, and an autonomous maintenance system is proposed and will be explained in the next section.

\section{Autonomous Maintenance}

Based on the low-performance efficiency value in the ORE calculation, it needs action to solve this problem. The investigation has been done, and one of the causes of low-performance efficiency is the less responsiveness of the operator when the machine has some trouble or needs a simple repair. In the meantime, a limited of maintenance technicians handling all maintenance works have been affected by this condition. To minimize the problem of lowperformance efficiency, and autonomous maintenance was proposed. Autonomous maintenance is a willing concept that gives machine operators the responsibility for basic maintenance tasks, rather than relying on dedicated maintenance technicians. Autonomous maintenance has two key points, which is the first is to prevent equipment deterioration through a proper operation and the second is keeping the machine or equipment "like a new" through the proper maintenance action.

Before the implementation of this autonomous maintenance, training was conducted for operators regarding the basic replacement of parts and maintenance on a small scale by the operators themselves. After that, the operator gets a detailed explanation regarding the maintenance of the paving molding machine by predetermined standards. Therefore, operators are given confidence in the machines they operate to maintain the machines and understand the functions and roles of these machines so that the company's production targets can be achieved. In implementing autonomous maintenance, seven steps need to be considered, as follows.

First is initial cleaning. The initial cleaning is the initial maintenance of the paving molding machine which is carried out to restore the condition of the machine to its initial condition. Activities carried out for equipment activities include the following.

a. Activities are led by PT XYZ's maintenance department to provide safety instructions.

b. Distribute equipment to operators for cleaning.

c. Clean the contaminated area. 
Table 2. Machine Cleaning Checkpoints (Modified from Delhi, 2010)

\begin{tabular}{|c|c|}
\hline \multicolumn{2}{|l|}{ Nuts and Bolts } \\
\hline Slight Defects & $\begin{array}{l}\text { - Are nuts and bolts loose? } \\
\text { - Are nuts and bolts missing? }\end{array}$ \\
\hline $\begin{array}{l}\text { Attachment of Nuts } \\
\text { and Bolts }\end{array}$ & $\begin{array}{l}\text { - Are nuts installed from below and visible from the outside? } \\
\text { - Is the wing installed correctly? }\end{array}$ \\
\hline \multicolumn{2}{|l|}{ Lubrication } \\
\hline Lubrication Storage & $\begin{array}{l}\text { - Has the lubricant storage been arranged properly through the application of } \\
5 \text { S principles? } \\
\text { - Is the lubricant always covered when not in use? } \\
\text { - Is there control over the lubricant stock? }\end{array}$ \\
\hline Lubricant Inlets & $\begin{array}{l}\text { - Are the inlet and lubricating ports always clean and dustproof? } \\
\text { - Is there a label marking and lubricant quantity for the lubricant inlet? }\end{array}$ \\
\hline $\begin{array}{l}\text { Lubrication } \\
\text { Condition }\end{array}$ & $\begin{array}{l}\text { - Are the lubrication conditions for rotating parts and transmission systems in } \\
\text { the machine always lubricated regularly? } \\
\text { - Is the environment around the lubrication clean and not contaminated? }\end{array}$ \\
\hline \multicolumn{2}{|l|}{ Transmission System } \\
\hline Roller Chains & $\begin{array}{l}\text { - Is there a stretched or worn chain? } \\
\text { - Are the sprocket teeth missing or damaged? } \\
\text { - Is the amount of lubrication on the roller chains sufficient? }\end{array}$ \\
\hline Bearing & $\begin{array}{l}\text { - Is the bearing giving off excessive heat, vibration, or abnormal sound? } \\
\text { - Is there any looseness in the bolts and keys? }\end{array}$ \\
\hline Gear & $\begin{array}{l}\text { - Is the lubricant for the gear correct and the surrounding environment clean? } \\
\text { - Are there any teeth worn, missing, damaged? } \\
\text { - Does it produce unusual sounds and vibrations when operating? }\end{array}$ \\
\hline \multicolumn{2}{|l|}{ Hydraulic } \\
\hline Piping and Wiring & $\begin{array}{l}\text { - Are all pipes and hoses properly installed? } \\
\text { - Is the hose damaged and there is a leak of fluid in the pipe? } \\
\text { - Are all valves working properly? } \\
\text { - Are there any unnecessary pipes, cables, or vales? }\end{array}$ \\
\hline \multicolumn{2}{|l|}{ Electrical } \\
\hline Electrical Equipment & - Are there electrical components overheating, vibration, and unusual smells? \\
\hline Sensors & $\begin{array}{l}\text { - Is all limit switch that is not installed properly? } \\
\text { - Are there sensors that are not properly positioned? } \\
\text { - Are all sensors installed according to the type and location? }\end{array}$ \\
\hline Switches & $\begin{array}{l}\text { - Are all manual switches clean, undamaged, and free from excessive play? } \\
\text { - Are the installed switches in the correct position? } \\
\text { - Has the emergency installation been in a suitable location and worked } \\
\text { properly? }\end{array}$ \\
\hline
\end{tabular}

d. Clean the machine from top to bottom and from the inside out, including hidden and chronically neglected areas. For important parts of the machine, such as nuts and bolts, be careful and careful because they can loosen and come off.

e. Emphasize to the operator that "cleaning as inspection" and this paving press is the operator's responsibility because it is used for the production process.

f. Every operator must participate in cleaning and find out abnormalities and or problems in the machine. g. Mark the components or equipment on the paving press for further repairs.

h. If there is a problem with the paving press, an action plan for repair is carried out.

i. Make a regular cleaning schedule to keep the machine clean and find out other abnormalities.

Table 2 shows checkpoints for several components on the paving molding machine that are carried out during cleaning. Based on Table 2, if this step can be carried out it will produce benefits for the company, namely the machine is clean, zero loose nuts and bolts, all abnormalities 
in the machine can be identified. While the benefits for operators are that all operators must understand the purpose of "autonomous maintenance" and all operators can participate in activities to support autonomous maintenance.

\section{Countermeasure at the source of problems}

After the initial cleaning activity is carried out, further analysis is carried out on the causes of the problem checking so that it can reduce damage. In this step, several activities are carried out, including the following.

a. Understand the basics of cleaning paving presses.

b. Measure cleaning time and apply Kaizen hardto-access areas.

c. Prepare interim standards for cleaning, lubrication, and tightening.

d. Lubricate the paving molding machine.

e. Take photos before and after standard cleaning.

f. Conduct periodic audits.

There are benefits obtained after doing this step, namely for clean machines, zero breakdown, zero defects, high reliability, and availability of machines, while for operators, they can form an attitude of analyzing and solving problems and getting used to doing "preventive action".

\section{Cleaning and lubrication standards}

After the initial cleaning activities have been carried out and identify the sources of the damage problem, then the standard for cleaning and lubrication is set so that the operator gets used to cleaning and checking the condition of the machine. For this step, a standard that is easy to understand and lightweight is set so that it can be understood by the operator. The benefits for the activities that have been carried out at this stage are that the operator can increase knowledge, confidence, responsibility, and feel the importance of maintaining the state of the machine.

\section{General inspection}

Machine inspection activities are carried out by the operator so that the operator must be able to understand the structure, function, and proper inspection method. CLT (Cleaning, Lubricating, Tightening) is an activity that will be applied by the operator to the machine. The benefits for the operator at this stage are that they can learn about the components of the paving molding machine.

\section{Autonomous inspection}

This step is taken by the operator to prevent defective products from being produced and achieve zero defects. The existence of independent maintenance standards and maintenance schedules can increase knowledge about paving printing machines and maintain the quality of the products produced.

\section{Organization and tidiness}

In this step, the operator can identify the work environment being managed and create standards for the work environment and safety during the production process. Operators make work standards for paving machines to be adhered to during the production process. In implementing this autonomous maintenance, operators are given training as follows:

a. Education - Machine Function. In this step, a basic understanding of the components and functions of the paving machine is carried out.

b. Initial Clean \& Inspect. In this step, training is carried out on detecting machine problems, setting standards, and awareness of paving machines so that the work environment becomes better reduces accidents and helps improve machine efficiency.

c. Eliminate Contamination \& Inaccessible areas. In this step, training is on maintaining hygiene standards, identifying, and repairing them quickly. Training is carried out by identifying sources of contamination, identifying inaccessible areas.

d. Develop "Provisional" Standard. In this step, training on hygiene standards, lubrication standards, inspection standards, and maintenance schedules. The standards that have been made are presented to the whole team and given an understanding to the operator and posted on the work area board. 


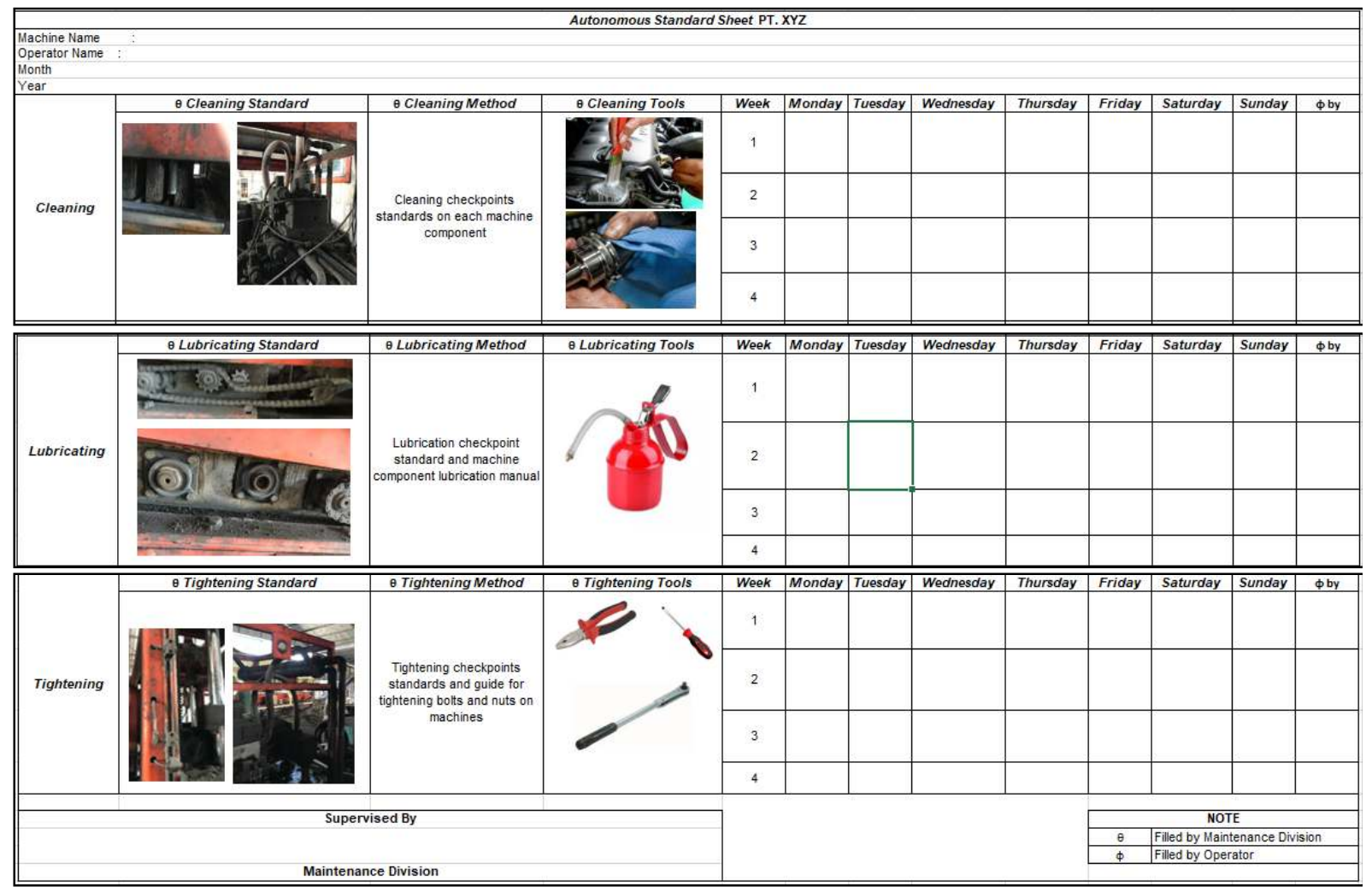

Figure 10. Autonomous maintenance Sheet Form

e. Finalize Standards \& Train. In this step, training is carried out with structured training consisting of the name of the part, structure, and function of the machine, problems and corrective actions, inspection criteria. The benefit for operators at this stage is that they can realize the importance of setting standards and procedures in the company based on analysis and actual in the field.

\section{Full Autonomous Maintenance}

At this step, the operator is proficient and able to perform maintenance on the machine used. If the operator is capable, then the company's policies and objectives can be further developed. Continuous improvement is carried out based on the analyzes that have been carried out previously and the results of the effectiveness of the paving molding machine.

Figure 10 shows, the proposed autonomous maintenance sheet form which consists of the CLT (Cleaning, Lubricating, and Tightening) activities for the machine operators. The column for cleaning standard, lubricating standard, and tightening standard contains standards for cleanliness, lubrication, and tightening on machines and the operator's work environment. The cleaning method, lubricating method, and tightening method columns contain methods for cleaning, lubricating, and tightening machines following company standards and policies. The cleaning tools, lubricating tools, and tightening tools columns contain the equipment used in cleaning, lubricating, and tightening machines. This CLT form must be filled by the machine operator and closed with the signature of the person in charge of the activity, in these cases is the machine operator under the supervision and checked by the engineering maintenance supervisor.

As a closing discussion, based on previous research on machine performance analysis, most of the researcher focuses on the OEE or ORE analysis only, without considering the several pillars in TPM which can improve the machine performance. Therefore, this paper considers the 
proposed autonomous maintenance by the machine's operator using the seven steps of the autonomous maintenance system. Then a basic CLT (Cleaning, Lubricating, Tightening) form activities are designed for the machine's operator. The standards form that have been set and designed previously, can be evaluated, and improved due to the operator's ability and skill in the basic machine maintenance system.

Autonomous maintenance as one of the pillars of TPM is in increasing machine effectiveness by utilizing and optimizing the machine operator and creating a sense of belonging to the machine's performance. The implementation of autonomous maintenance can increase the company's resources skill, especially operators because machine maintenance is carried out independently by the operator, while on the other hand also improving the performance efficiency and increasing the reliability, availability, and productivity of the machine.

\section{CONCLUSION}

Overall, this paper analyzed the effectiveness of the paving molding machine using the ORE method. The result of the ORE analysis becomes a basic design of autonomous maintenance. Based on the ORE method, the average result of calculating the overall effectiveness of the paving molding machine is relatively low; $64.54 \%$ which is caused by one of the machine values, that is performance efficiency in $77.98 \%$. To increase the ORE value, especially in the low-performance efficiency value, a proposed implementation of autonomous maintenance is carried out. There are seven steps in the implementation of autonomous maintenance, specifically initial cleaning, countermeasure at the source of problems, cleaning and lubrication standards, general inspection, autonomous inspection, organization and tidiness, full autonomous maintenance. The details of each step of autonomous maintenance are explained and the basic autonomous maintenance sheet form (CLT sheet) is presented. This CLT sheet becomes a basic form for starting the implementation of autonomous maintenance of the paving molding machine by the operator. Using this basic CLT, the operator can learn about the components of the paving molding machine, detect the basic machine problems, as well as the operator is given the responsibility to maintain the basic condition of the machine to minimize further damage of the paving molding machine. In the future, the development and implementation of this autonomous maintenance system must be evaluated and can combine another pillar in TPM such as planned and quality maintenance.

\section{REFERENCES}

Alhilman, J., \& Abdillah, A. F. (2019). Analysis of Double indian Ballbreaker Net Sorter Machine Based on Overall Equipment Effectiveness Method Cases in Tea Plantation Plants. IOP Conference Series: Materials Science and Engineering, 528(1). https://doi.org/10.1088/1757-899X/528/1/012046

Aprina, B. (2019). Analisa Overall Resource Effectiveness Untuk Meningkatkan Daya Saing Dan Operational Excellence Jurnal IImiah Teknik Dan Manajemen Industri, 2.

Bokrantz, J., Skoogh, A., Berlin, C., Wuest, T., \& Stahre, J. (2020). Smart Maintenance: an empirically grounded conceptualization. International Journal of Production Economics, 223. https://doi.org/10.1016/j.ijpe.2019.107534

Budihardjo, I., \& Marisa, D. (2009). Autonomous Maintenance Untuk Meningkatkan Produktivitas Produksi Di Pilot Line Factory 4. Inasea, 10 (1), 1933.

Delhi, N. (2010). Support from Autonomous Maintenance (Jishu Hozen) for Breakdown Elimination Conference on Maintenance Practices through TPM to achieve ZERO Breakdown Why Breakdown? It's only due to Deterioration. August.

Dewi, S., Alhilman, J., \& Atmaji, F. T. D. (2020). Evaluation of Effectiveness and Cost of Machine Losses using Overall Equipment Effectiveness (OEE) and Overall Equipment Cost Loss (OECL) Methods, a case study on Toshiba CNC Machine. IOP Conference Series: Materials Science and Engineering, 847(1). https://doi.org/10.1088/1757899X/847/1/012020

Eswaramurthi, K. G., \& Mohanram, P. V. (2013). Improvement of manufacturing performance measurement system and evaluation of overall resource effectiveness. American Journal of Applied 

Sciences,
10
(2),
$131-138$

https://doi.org/10.3844/ajassp.2013.131.138

Ferreira, C. W. T., \& Leite, J. C. (2016). Applied autonomous maintenance in the improvement of production quality: a case study. ITEGAM - Journal of Engineering and Technology for Industrial Applications (ITEGAM-JETIA), 2. https://doi.org/10.5935/2447-0228.20160026

Alhilman, J. \& Atmaji, F. (2017). Software Application for Maintenance System. 2017 Fifth International Conference on Information and Communication Technology (ICoICT), 0(RCM II), 470-475.

Priyono, S., Machfud, M., \& Maulana, A. (2019). Penerapan Total Productive Maintenance (TPM) Pada Pabrik Gula Rafinasi di Indonesia (Studi Kasus: PT. XYZ). Jurnal Aplikasi Bisnis Dan Manajemen, 5 (2), 265-277. https://doi.org/10.17358/jabm.5.2.265

Salsabila, J. R., Atmaji, F. T. D., \& Pramoso, A. (2020). Maintenance Cost Analysis Using Cost of Unreliability (COUR) Method with Business Consequence Analysis: A Case Study of Shot Blast Machine. Jurnal Ilmiah Teknik Industri, 19 (2), 223234. https://doi.org/10.23917/jiti.v19i2.11961

Tsarouhas, P. H. (2013). Evaluation of overall equipment effectiveness in the beverage industry: A case study. International Journal of Production Research, 51(2), 515-523.

https://doi.org/10.1080/00207543.2011.653014

Workineh, M. W., \& Iyengar, A. S. (2014). Autonomous Maintenance: A Case Study on Assela Malt Factory. Bonfring International Journal of Industrial Engineering and Management Science, 4 (4), 170178. https://doi.org/10.9756/bijiems.10364 